\title{
Long-Term Impacts of Wastewater Irrigation on Cuban Soils
}

\author{
A. Rosabal \\ E. Morillo \\ T. Undabeytia \\ C. Maqueda* \\ Instituto de Recursos \\ Naturales y Agrobiologia (CSIC) \\ Apdo. 1052 \\ 41080 Sevilla, Spain
}

\author{
A. Justo \\ Instituto de Ciencia de Materiales \\ (UNSE-CSIC) \\ Isla de la Cartuja \\ 41092 Sevilla, Spain
}

\section{Juan F. Herencia \\ Centro de Investigación y Formación Agraria "Las Torres-Tomejil" (C.I.F.A.) \\ Alcalá del Rio, Sevilla, Spain}

\begin{abstract}
The disposal of wastewater, known as vinasse, from the sugarcane (Saccharum officinarum L.) industry creates environmental problems. Agriculture can offer a potential solution to these problems by using organic residues as substitutes for chemical fertilizers. This study was conducted in Ultisol profiles from Cuba irrigated with vinasse for $40 \mathrm{yr}$. The effects of this application on physicochemical and mineralogical properties of soils were investigated. Soils fertilized with traditional inorganic fertilizers were used for comparison. Fertilization with the wastewater caused a decrease of soil $\mathrm{pH}$ to a depth of $100 \mathrm{~cm}$. There was an increase, however, in electrical conductivity because of the large concentration of $\mathrm{K}$ in the wastewater. The amendment also increased the organic matter content throughout the profile. Vinasse application yielded the intercalation of some compounds in the clay mineral smectite. The formation of organo-mineral complexes produced little change in the particle size distribution, but an increase in the poorly crystalline Fe oxyhydroxides in the upper horizon up to $22 \%$, and the crystallinity of Fe oxyhydroxide in the soil decreased substantially. This was probably due to dissolution and reprecipitation of these oxides by the acid $\mathrm{pH}$ of the wastewater. Total and poorly crystalline Mn contents also decreased. The amendment material increased the mobility of metals because of the formation of water-soluble complexes with organic ligands. The results showed that long-term wastewater irrigation could be of agricultural interest due mainly to its organic matter concentration, but micronutrient concentrations in the upper horizons were negatively affected because complexing of metals favored their transport throughout the soil profile, which may eventually lead to deterioration of groundwater quality and micronutrient deficiency.
\end{abstract}

Abbreviations: $\mathrm{DCB}$, dithionite-citrate-bicarbonate; EC, electrical conductivity; $\mathrm{Fe}_{\mathrm{d}}$, iron oxides extracted by dithionite-citrate-bicarbonate; $\mathrm{Fe}_{\mathrm{o}}$, iron oxides extracted by oxalate-oxalic acid in the dark; $\mathrm{Mn}_{\mathrm{d}}$, manganese oxides extracted by dithionite-citrate-bicarbonate; $\mathrm{Mn}_{\mathrm{o}}$, manganese oxides extracted by oxalate-oxalic acid in the dark; OM, organic matter; XRD, $\mathrm{x}$-ray diffraction.
$\mathrm{I}^{\mathrm{n}}$ $\mathrm{n}$ areas with extensive production of sugarcane, disposal of the residues from manufacturing plants of this agricultural product represent a major concern (Cruz et al., 1991; Gloeden et al., 1991). Production of sugar and its derivatives is the primary industry of Cuba. These factories yield great quantities of effluents that are discharged untreated into the sea and can cause environmental problems. This agroindustrial material can be used as a substitute for chemical fertilizers, as it contains significant amounts of organic matter and plant nutrients. Application of byproducts from the sugarcane industry could be one of the most economical and suitable methods to solve two problems: wastewater disposal and soil fertilization. Cuba has adopted its utilization, to a large extent, in the irrigation of sugarcane plantations.

Solid organic components in wastes added to soils provide new exchange sites for cations as well as other adsorption sites. Diaz-Barrientos et al. (2003) and Rodriguez-Rubio et al.

Soil Sci. Soc. Am. J. 71:1292-1298

doi:10.2136/sssaj2006.0248

Received 3 July 2006.

*Corresponding author (celia@irnase.csic.es).

(c) Soil Science Society of America

677 S. Segoe Rd. Madison WI 53711 USA

All rights reserved. No part of this periodical may be reproduced or transmitted in any form or by any means, electronic or mechanical, including photocopying, recording, or any information storage and retrieval system, without permission in writing from the publisher. Permission for printing and for reprinting the material contained herein has been obtained by the publisher.
(2003) observed that organic matter and carbonate in soils are the most important components regarding metal retention. Organic molecules with the capability to complex metals can potentially increase concentrations of these metals in the soil solution by dissolution reactions at mineral surfaces. Therefore, organic amendments can increase the solubility of metals by producing ligands that chelate the metals, thereby blocking their adsorption and promoting leaching through formation of soluble metal complexes (Madrid and Diaz-Barrientos, 1998). Organic matter can modify the $\mathrm{pH}$, influencing the nature and extent of metal retention. Strobel et al. (2005) showed that dissolved organic carbon (DOC) enhanced the release of $\mathrm{Cu}$ from $<8 \%$ to $>20 \%$ of extractable Cu. Del Castilho et al. (1993) found a significant increase in $\mathrm{Cd}$ and $\mathrm{Zn}$ in the soil solution of an organically amended soil. The availability of Fe was also affected by the formation of complexes of Fe with DOC (Raulund-Rasmussen et al., 1998).

The effect of vinasse application on soil was studied by Casarini et al. (1987). They observed an initial decrease in $\mathrm{pH}$ after its application, though later the $\mathrm{pH}$ increased again. Vinasse also caused an increase in $\mathrm{Na}$ and $\mathrm{Mn}$ contents to levels that were not toxic to crops, and also observed an increase in $\mathrm{K}$ that was beneficial to the crops. Mattiazzo and Dagloria (1987) found that vinasse application caused an initial $\mathrm{pH}$ reduction that increased with time because of microbial activity causing oxidation of the organic matter. Stepkowska et al. (2001) found that cyclic fertilization with vinasse improved the agrotechnical properties of soils, depending on the soil type. 
Benke et al. (1998) studied the composition of vinasse from different sugarcane distilleries and found that the DOC from these samples was generally similar to the spectra of the fulvic acids of soils and sewage sludge. The spectra of the DOC differed from that of the fulvic acids, having a smaller amount of aromatic $\mathrm{C}$ and an absence of amine groups. It has been found that this functional group may be responsible for the dissolution of metals. Other researchers also indicated that DOC in soils plays an important role in the transport of nutrients (Qualls and Haines, 1991) and trace elements through surface transport and leaching. The byproduct from sugarcane contains high amounts of DOC, varying from 10.973 to $14.801 \mathrm{~g} \mathrm{~L}^{-1}$ (Benke et al., 1999), which could have a noticeable effect on the status of soil metals after a few consecutive years of irrigation. While the effect of sewage sludge on the soil system has been extensively studied, investigations regarding the relationships between metals and wastewater from the sugarcane industry are scarce. In addition, it is very important to study the long-term effect on the soil residual system, because many of these studies were performed after 1 to 3 yr of application.

The objective of the present study was to determine the effect of sugarcane wastewater irrigation for $40 \mathrm{yr}$ on ferralitic soils from the La Habana province in Cuba - more specifically, the effect on: (i) some physicochemical properties of the soil, (ii) the clay minerals, (iii) the $\mathrm{Fe}$ and $\mathrm{Mn}$ oxide content, (iv) the mobility of $\mathrm{Cu}, \mathrm{Zn}$, and Co in the profile, and (v) crop yield. Results were compared with those obtained under traditional mineral fertilization.

\section{MATERIALS AND METHODS}

The study area is located in the province of La Habana, in Cuba. Soils were classified as Ultisols according to Soil Survey Staff (1999). They are Ferralitic Yellow soils, with parent materials of calcareous rock. The extent of these Yellow Ferralitic soils in this province is about 76200 ha. The soils used were classified as fine, smectitic, isohyperthermic Aquic Dystric Eutrudepts. They have two horizons and aquic conditions during certain periods in regular years and do not have free carbonates throughout any horizon in the first $100 \mathrm{~cm}$ of the soil profile. The water regime of these soils is udic and the temperature isohyperthermic because the average temperature of the soils is $22^{\circ} \mathrm{C}$ or higher and the differences between winter and summer is $<6^{\circ} \mathrm{C}$.

La Habana Province has 50-yr mean temperature values of $25.1^{\circ} \mathrm{C}$, a maximum of $27.2^{\circ} \mathrm{C}$ in July and August, and a minimum in January of $22.1^{\circ} \mathrm{C}$ (Ministerio de Agricultura de Cuba, 1985). With respect to rain, there is a wet period in the summer and a dry period in winter. The mean pluviometric value is $1454 \mathrm{~mm}$, with June and September being the wettest months.

The study was performed in profiles from a field after irrigation with wastewater from sugarcane production for $40 \mathrm{yr}$ (referred to as treated soils). In a parallel study, plots that were not irrigated with sugarcane wastewater (control plots) were used for comparison (referred to as untreated soils). Four replicates per system were established (eight profiles). The sizes of the fields were about 13 and 15 ha for untreated and treated soils, respectively. The distance between the fields was $500 \mathrm{~m}$.

Soil samples were collected at three depths for each horizon: 0 to10, 10 to 20 , and 20 to $30 \mathrm{~cm}$ for the Ap horizon, and 30 to 50, 50 to 70 , and 70 to $100 \mathrm{~cm}$ for the Bwg horizon. The samples were initially air dried and sieved ( $<2-\mathrm{mm}$ mesh size), and stored for analyses. Soil $\mathrm{pH}$ and electric conductivity (EC) were determined in the 1:5 soil/water extract, and organic matter (OM) by potassium dichromate oxidation. Particle-size distribution was measured by the Bouyoucos densimeter (Gee and Bauder, 1979).

The clay fraction was separated by suspension. Because of the relatively large amount of Fe oxides of these soils, they were removed before the determination of the type of clay minerals. The clay minerals $(<2 \mu \mathrm{m})$ were characterized by $x$-ray diffraction (XRD) before and after extraction with oxalate-oxalic acid solution in the dark and dithionite-citrate-bicarbonate (DCB) solution, using $\mathrm{Cu} \mathrm{K} \alpha$ radiation and using oriented samples sedimented on glass slides and treated with $\mathrm{Mg}^{2+}, \mathrm{Mg}^{2+}$-ethylene glycol, or $\mathrm{K}^{+}$saturated solutions followed by heating at $550^{\circ} \mathrm{C}$. A semiquantitative estimate of non-Fe minerals was determined using the reflection powers given by Schultz (1964).

The content of amorphous oxides and organically bound $\mathrm{Fe}$ $\left(\mathrm{Fe}_{\mathrm{o}}\right)$ and $\mathrm{Mn}\left(\mathrm{Mn}_{\mathrm{o}}\right)$ were determined according to McKeague et al. (1971). The samples were treated with ammonium oxalate-oxalic acid in the dark. Free $\mathrm{Fe}$ and $\mathrm{Mn}$ oxides $\left(\mathrm{Fe}_{\mathrm{d}}\right.$ and $\left.\mathrm{Mn}_{\mathrm{d}}\right)$ were determined by the method of Mehra and Jackson (1960) with DCB. Iron and Mn contents were analyzed in the DCB extract and in the oxalate-oxalic acid solution. Iron and Mn contents were measured using an inductively coupled plasma-atomic emission spectrometer (ICP-OES) and given as $\mathrm{Fe}_{2} \mathrm{O}_{3}$ and $\mathrm{MnO}$.

The total metal contents of the soils were determined by dissolving the samples using a three-acid method (Perez-Rodríguez et al., 1990), and the elements measured using ICP-OES.

The wastewater used was from the cooperative Pedrín Troya located in the Complejo Agroindustrial Hector Molina Riaño (La Habana Province, Cuba). The wastewater used came from the raw fabrication of sugar and alcohol. Water from the sugarcane industry and from alcohol distillation are mixed $100 \mathrm{~m}$ away from the factories into a channel that discharges into the sea. Part of this wastewater, however, was used for soil irrigation at a flow of $4 \mathrm{~L} \mathrm{~s}^{-1}$ for several days until total flooding. This type of irrigation by flooding on the treated plots was performed once per year. Some characteristics of the wastewater are shown in Table 1 . The treated soils were irrigated for $40 \mathrm{yr}$ and this study presents the results after this period of treatment.

The fields of the untreated (control) and treated soils were planted for $40 \mathrm{yr}$ with sugarcane of the cultivar Cuba-8751. The control fields received conventional fertilization $(\mathrm{N}, \mathrm{P}$, and $\mathrm{K})$. The fields irrigated with wastewater received organic fertilization from the wastewater and inorganic $\mathrm{N}$ amounting to one-third of that supplied to the unirrigated sites.

\section{Statistical Analysis}

Statistical analyses were performed using ANOVA. The means were separated by Tukey's test at a significance level of $P<0.05$ throughout the study.

\section{RESULTS AND DISCUSSION Influence of Irrigation on pH, Organic Matter Content, and Electrical Conductivity}

The application of the wastewater had noticeable effects on certain soil chemical properties. The reaction $\mathrm{pH}$ of the untreated soils was 7 or near neutrality. The mean $\mathrm{pH}$ values of the treated soils showed a decrease of about $0.5 \mathrm{pH}$ units for all depths (Table

Table 1. Some characteristics of the wastewater used in this study.

\begin{tabular}{|c|c|c|c|c|c|c|}
\hline $\mathrm{pH}$ & DOMt & $\mathbf{P}$ & $\mathrm{Na}$ & K & $\mathrm{Ca}$ & $\mathrm{Mg}$ \\
\hline & $\mathrm{g} \mathrm{L}^{-1}$ & 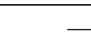 & 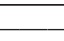 & $\mathrm{g} \mathrm{L}^{-1}$ & & 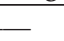 \\
\hline 5.02 & 50 & 205.6 & 146 & 382 & 325 & 76.8 \\
\hline
\end{tabular}


Table 2. Mean values of $\mathrm{pH}$, electrical conductivity (EC), and organic matter (OM) of untreated and treated samples.

\begin{tabular}{|c|c|c|c|c|c|c|}
\hline \multirow{2}{*}{ Depth } & \multicolumn{2}{|c|}{$\mathrm{pH}$} & \multicolumn{2}{|c|}{ EC } & \multicolumn{2}{|c|}{ OM } \\
\hline & Untreated & Treated & Untreated & Treated & Untreated & Treated \\
\hline $\mathrm{cm}$ & & & 2 & & 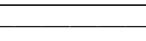 & \\
\hline $0-10$ & 7.1 at & $6.7 \mathrm{~b}$ & $0.12 \mathrm{a}$ & $0.25 \mathrm{~b}$ & $20.4 \mathrm{a}$ & $28.6 \mathrm{a}$ \\
\hline $10-20$ & $7.5 \mathrm{a}$ & $7.0 \mathrm{ab}$ & $0.11 \mathrm{a}$ & $0.27 \mathrm{~b}$ & $15.7 b$ & $26.6 \mathrm{a}$ \\
\hline $20-30$ & $7.4 \mathrm{a}$ & $6.9 \mathrm{ab}$ & $0.11 \mathrm{a}$ & $0.33 \mathrm{~b}$ & $8.7 \mathrm{~b}$ & $22.7 \mathrm{a}$ \\
\hline $30-50$ & $7.4 \mathrm{a}$ & $6.8 \mathrm{ab}$ & $0.09 \mathrm{a}$ & $0.21 \mathrm{~b}$ & $5.2 \mathrm{~b}$ & $12.3 \mathrm{~b}$ \\
\hline $50-70$ & $7.5 \mathrm{a}$ & $6.9 \mathrm{ab}$ & $0.08 \mathrm{a}$ & $0.11 \mathrm{a}$ & $2.0 \mathrm{C}$ & $4.0 \mathrm{C}$ \\
\hline $70-100$ & $6.2 \mathrm{~b}$ & $5.9 \mathrm{C}$ & $0.08 \mathrm{a}$ & $0.08 \mathrm{a}$ & $0.3 \mathrm{~d}$ & $2.0 \mathrm{C}$ \\
\hline
\end{tabular}

+ Values followed by the same letter in the analyzed properties for untreated and treated soils are not significantly different $(P<0.05)$.

2). Long-term changes in soil $\mathrm{pH}$ occur largely as a result of displacing cations or adding weak organic acids (Tisdale et al., 1993). The $\mathrm{pH}$ value of the wastewater was much lower (about $2 \mathrm{pH}$ units) than that of the soils studied, but the $\mathrm{pH}$ decrease of the treated soil was small because of the buffering capacity of the soil.

The EC increased greatly after the long-term irrigation (Table 2). This was attributed to the large concentration of $\mathrm{K}$ in this wastewater $\left(382 \mathrm{mg} \mathrm{L}^{-1}\right)$. The values were always less

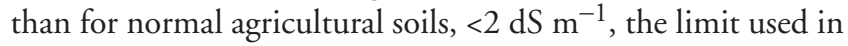
the salt tolerance of crops (Bresler et al., 1982). Madejon et al. (2001) found that when vinasse was applied on two different occasions, there was no effect on the mean $\mathrm{pH}$ value. These researchers found high EC values, however, which indicated that caution should be used for soils with restricted drainage.

The OM contents of these soils was between 20.4 and $0.3 \mathrm{~g} \mathrm{~kg}^{-1}$ for the top- and subsoils. The increase in soil OM was one of the effects of wastewater application to the soil. The $\mathrm{OM}$ of the treated profiles increased (Table 2) with the addition of organics in the wastewater. This increase ranged between 40 and $500 \%$, with the higher increase at a depth of 70 to $100 \mathrm{~cm}$. This is due, in part, to the very small OM concentration at the bottom of the profiles, and consequently, any increase in OM resulted in high values when expressed as a percentage of the initial amount. Using sugarbeet (Beta vulgaris L. subsp. vulgaris) vinasse, Madejon et al. (2001) found that soil oxidizable C significantly increased in soil treated with the organic amendment, and the differences were statistically significant in most cases.

\section{Influence on Particle Size Distribution}

The clay content of the untreated soils increased with depth (Table 3), while the mean silt content decreased. The sand content also decreased with depth, but the difference was not statistically significant.

Irrigation with wastewater caused a decrease in the clay fraction at all depths in comparison with the untreated soils, although these differences were not significant in the top $20 \mathrm{~cm}$; as a consequence, an accumulation of the silt fraction occurred along the pro- file. This behavior could be related with an association of the added organic matter with the clay fraction (formation of organo-mineral complexes), giving an increase in the particle size of this fraction. In addition, the dissolution and precipitation of Fe oxides may coat the particles, acting as cement, and bind the particles together. The dispersant used for the determination of the textural fractions of the soils (sodium hexametaphosphate) did not readily dispersed the soil and may have altered the particle size distribution.

The amount of silt-sized particles in the subsoil of the treated soils increased more than that in the topsoil (Table 3) about 200 and $2 \%$, respectively. This was due, in part, to the fact that the silt contents in the subsoil at the bottom of the profiles were less than in the untreated soils and the increases were significant. Others have also found that vinasse application to soil caused a difference in the textural fractions and this distribution was dependent on soil type (Stepkowska et al., 2001).

\section{Influence of Irrigation on the Clay Minerals of Soil}

The XRD patterns for the clay fraction of two representative profiles (untreated and treated soils) are shown in Fig. 1. The XRD diagram of the clay fraction of the untreated soil shows a peak at about $14 \AA$ that expanded to $18 \AA$ with ethylene glycol (data not shown). The treatment with $\mathrm{K}$ and subsequent heating at $550^{\circ} \mathrm{C}$ for $30 \mathrm{~min}$ decreased the $14 \AA$ peak to $10 \AA$ (data not shown). These data confirmed that the predominant clay mineral was of smectite type. The peaks at $7.14,4.43$, and $3.55 \AA$ that remain after treatment with ethylene glycol confirmed the presence of kaolinite in a large proportion. The semiquantitative estimation of the phyllosilicate minerals, using the reflection powers given by Schultz (1964), is 65\% smectite, 35\% kaolinite. Removal of the Fe oxides in this soil was necessary for the characterization of the clay minerals by XRD.

The XRD data for the soil after $40 \mathrm{yr}$ of treatment showed a decrease in intensity and broadening and asymmetry of the diffraction peak at $14 \AA$ that expanded to $18 \AA$ with ethylene glycol, corresponding to smectite. The $\mathrm{Mg}^{2+}$ saturation was performed to obtain homoionic clay in the interlayer space. In the treated soil, however, the peak was broad and not well defined, which may be

Table 3. Mean values of particle size distribution of untreated and treated soil samples.

\begin{tabular}{|c|c|c|c|c|c|c|}
\hline \multirow{2}{*}{ Depth } & \multicolumn{2}{|c|}{ Sand } & \multicolumn{2}{|c|}{ Silt } & \multicolumn{2}{|c|}{ Clay } \\
\hline & Untreated & Treated & Untreated & Treated & Untreated & Treated \\
\hline $\mathrm{cm}$ & & & 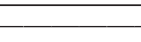 & & & \\
\hline $0-10$ & 306at & $328 a$ & $148 a$ & $151 \mathrm{a}$ & $547 a$ & $521 \mathrm{a}$ \\
\hline $10-20$ & 300a & $336 a$ & $125 a$ & $134 \mathrm{a}$ & $574 a$ & $529 a$ \\
\hline $20-30$ & $305 a$ & $323 a$ & $84 a b$ & $114 a$ & 610ab & $562 \mathrm{a}$ \\
\hline $30-50$ & $282 \mathrm{a}$ & $318 a$ & $97 a b$ & $124 \mathrm{a}$ & $620 \mathrm{ab}$ & $558 \mathrm{a}$ \\
\hline $50-70$ & $266 a$ & $286 a$ & $78 \mathrm{~b}$ & $112 \mathrm{a}$ & $660 b$ & $602 a$ \\
\hline $70-100$ & $277 a$ & $280 a$ & $40 c$ & $121 \mathrm{a}$ & $683 b$ & $598 a$ \\
\hline
\end{tabular}

+ Values followed by the same letter in each textural fraction for untreated and treated soils are not significantly different $(P<0.05)$. 
attributed to modification of the clay mineral to an organo-clay with the interlayer spaces occupied by mainly organic substances. This effect decreased with depth along the profile, being almost negligible in the lowest horizon (Fig. 1c). It was observed that in the treated soil, there was a greater difficulty in decreasing the $14 \AA$ peak to $10 \AA$ after treatment with $\mathrm{K}^{+}$, in comparison with the untreated soil, confirming the presence of organic substances in the interlayer space. The crystalline Fe oxide present in all the samples was goethite, with diffractions at $2.45,2.69$, and $4.18 \AA$.

\section{Influence on Iron and Manganese Oxides}

The mean Fe content of the samples from the different depths of the untreated profiles was between 93.3 and $108.8 \mathrm{~g} \mathrm{~kg}^{-1}$, with the highest content at a depth of 30 to $50 \mathrm{~cm}$. The mean values of total Fe for the treated soils were less than untreated soils (89.8-102.0 $\mathrm{g} \mathrm{kg}^{-1}$; Table 4).

The $\mathrm{Fe}_{\mathrm{o}}$ and $\mathrm{Fe}_{\mathrm{d}}$ contents are also shown in Table 4. The values of the short-range-ordered $\mathrm{Fe}$ oxide ( $\mathrm{Fe}_{\mathrm{o}}$, amorphous oxides) were in the range of 6.3 to 20.5 and 5.7 to $25.1 \mathrm{~g} \mathrm{~kg}^{-1}$ for untreated and treated soils, respectively, and the values decreased with depth with the exception of the sample from the 30- to 50-cm depth. Increased amounts of poorly crystalline $\mathrm{Fe}$ oxides in the upper layer of the treated soils were probably due to the organic matter accumulation, which may have retarded the effect of the crystallization of Fe oxides (Schwertmann, 1966). The content of crystalline oxides $\left(\mathrm{Fe}_{\mathrm{d}}-\mathrm{Fe}_{\mathrm{o}}\right)$ decreased in the same proportion, possibly because of the amorphisation of these oxides due to the acid $\mathrm{pH}$ of the wastewater; also, with regular water flooding, it is highly probable that reducing conditions occur that would bring about solubilization of Fe and $\mathrm{Mn}$ oxides and their subsequent precipitation as amorphous phases once the system becomes oxidizing again.

The $\mathrm{Fe}_{\mathrm{d}}$ value was used as a measure of the free Fe oxide content. The $\mathrm{Fe}_{\mathrm{d}}$ values had a uniform distribution through the profile and those values were, in general, less than for untreated soils. The $\mathrm{Fe}_{\mathrm{d}}$ values were logically larger than $\mathrm{Fe}_{\mathrm{o}}$ in all samples studied because DCB extracts both crystalline and amorphous oxides. The amount of Fe present in crystalline Fe oxides $\left(\mathrm{Fe}_{\mathrm{d}}-\mathrm{Fe}_{\mathrm{o}}\right)$ increased along the profile (except for the 30 - to $50-\mathrm{cm}$ depth), with values from 45.8 to 58.8 and 40.5 to $62.8 \mathrm{~g} \mathrm{~kg}^{-1}$ for untreated and treated soils, respectively. The difference between the total Fe content $\left(\mathrm{Fe}_{\mathrm{t}}\right)$ and $\mathrm{Fe}_{\mathrm{d}}$ corresponds to $\mathrm{Fe}$ in the silicate structure, by exchange of other cations or filling octahedral positions. These values were about one-third of the total Fe content and, in general, very constant along the profiles.

The $\mathrm{Fe}_{\mathrm{o}} / \mathrm{Fe}_{\mathrm{d}}$ ratio is an indication of the degree of crystallinity of free Fe oxides or aging of soils. Ratios $<0.12$ indicate that crystalline

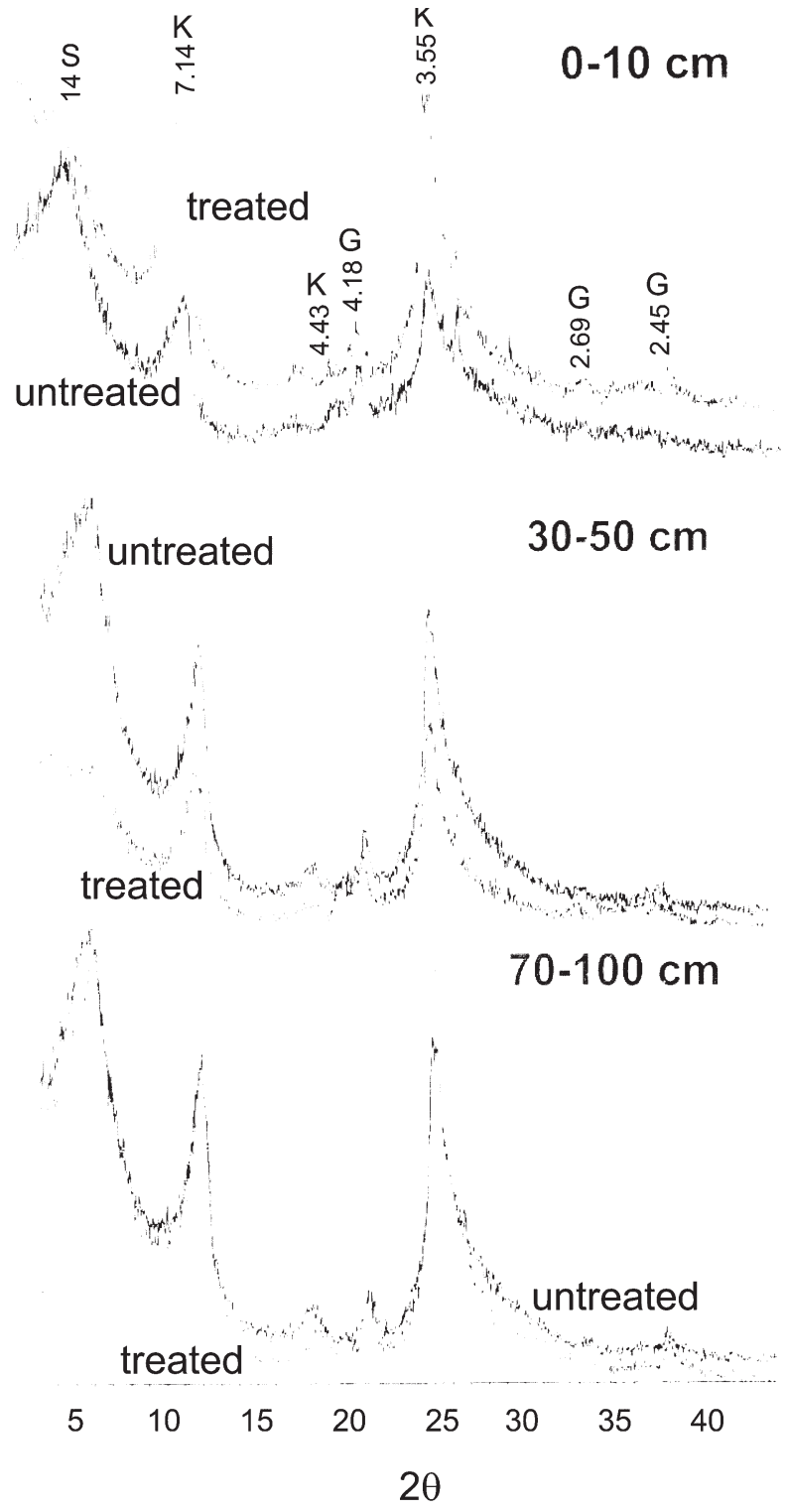

Fig. 1. X-ray diffraction pattern of the clay fraction of untreated and treated soils at three depths (S: smectite; K: kaolinite; G: goethite).

Fe oxides are dominant in the soils (Fitzpatrick and Schwertmann, 1982). High values of the $\mathrm{Fe}_{\mathrm{o}} / \mathrm{Fe}_{\mathrm{d}}$ ratio were found at the top of the profile where the organic matter content was the highest, which may have retarded the crystallization of Fe oxides. This can be also the consequence of a change in redox conditions.

Table 4. Average of total Fe oxides $\left(\mathrm{Fe}_{\mathrm{t}}\right)$, Fe oxides extractable by dithionite-citrate-bicarbonate $\left(\mathrm{Fe}_{\mathrm{d}}\right)$, Fe oxides extractable by oxalate-oxalic acid in the dark ( $\left.\mathrm{Fe}_{\mathrm{o}}\right)$, and indices in untreated (Untr) and treated (Tr) soils.

\begin{tabular}{|c|c|c|c|c|c|c|c|c|c|c|c|c|c|c|}
\hline \multirow{2}{*}{ Depth } & \multicolumn{2}{|c|}{$\mathrm{Fe}_{\mathrm{t}}$} & \multicolumn{2}{|c|}{$\mathrm{Fe}_{\mathrm{d}}$} & \multicolumn{2}{|c|}{$\mathrm{Fe}_{\mathrm{o}}$} & \multicolumn{2}{|c|}{$\mathrm{Fe}_{\mathrm{t}}-\mathrm{Fe}_{\mathrm{d}}$} & \multicolumn{2}{|c|}{$F e_{d}-F e_{o}$} & \multicolumn{2}{|c|}{$\mathrm{Fe}_{\mathrm{o}} / \mathrm{Fe}_{\mathrm{d}}$} & \multicolumn{2}{|c|}{$\mathrm{Fe}_{\mathrm{d}} / \mathrm{Fe}_{\mathrm{t}}$} \\
\hline & Untr & $\operatorname{Tr}$ & Untr & $\operatorname{Tr}$ & Untr & $\mathrm{Tr}$ & Untr & $\operatorname{Tr}$ & Untr & $\operatorname{Tr}$ & Untr & $\mathrm{Tr}$ & Untr & $\operatorname{Tr}$ \\
\hline $\mathrm{cm}$ & & & & & & & $\mathrm{kg}^{-1}$ & & & & & & & \\
\hline $0-10$ & 97.7 a† & $94.3 \mathrm{a}$ & $66.3 \mathrm{a}$ & $65.6 \mathrm{a}$ & $20.5 \mathrm{~b}$ & $25.1 \mathrm{ab}$ & 31.4 & 28.7 & 45.8 & 40.5 & 0.31 & 0.38 & 0.68 & 0.69 \\
\hline $10-20$ & $93.3 \mathrm{a}$ & $91.0 \mathrm{a}$ & $62.9 \mathrm{a}$ & $61.9 \mathrm{a}$ & $9.4 \mathrm{c}$ & $12.0 \mathrm{C}$ & 30.4 & 29.1 & 53.5 & 49.9 & 0.15 & 0.19 & 0.67 & 0.68 \\
\hline 20-30 & $93.5 \mathrm{a}$ & 89.8 a & $61.8 \mathrm{a}$ & $62.8 \mathrm{a}$ & $7.6 \mathrm{c}$ & $9.8 \mathrm{c}$ & 31.7 & 29.0 & 54.2 & 53.0 & 0.12 & 0.16 & 0.66 & 0.70 \\
\hline $30-50$ & $108.8 \mathrm{~b}$ & $95.4 \mathrm{a}$ & $64.4 \mathrm{a}$ & $66.1 \mathrm{a}$ & $18.1 \mathrm{~b}$ & $24.4 \mathrm{ab}$ & 44.4 & 29.3 & 46.3 & 41.7 & 0.28 & 0.37 & 0.59 & 0.69 \\
\hline $50-70$ & $103.0 \mathrm{~b}$ & $98.5 \mathrm{a}$ & $67.2 \mathrm{a}$ & $68.2 \mathrm{a}$ & $9.0 \mathrm{c}$ & $8.8 \mathrm{c}$ & 35.8 & 30.3 & 58.2 & 59.4 & 0.13 & 0.13 & 0.65 & 0.69 \\
\hline 70-100 & $104.0 \mathrm{~b}$ & $102.0 \mathrm{~b}$ & $65.1 \mathrm{a}$ & $68.5 \mathrm{a}$ & $6.3 \mathrm{~d}$ & $5.7 \mathrm{~d}$ & 38.9 & 33.5 & 58.8 & 62.8 & 0.10 & 0.08 & 0.63 & 0.67 \\
\hline
\end{tabular}

+ Values followed by the same letter in the analyzed Fe oxides for untreated and treated soils are not significantly different $(P<0.05)$. 
Table 5. Average of total $M n$ oxides $\left(M n_{t}\right), M n$ oxides extractable by dithionite-citrate-bicarbonate $\left(M_{d}\right)$, $M n$ oxides extractable by oxalate-oxalic acid in the dark $\left(\mathrm{Mn}_{0}\right)$, and indices in untreated (Untr) and treated (Tr) soils.

\begin{tabular}{|c|c|c|c|c|c|c|c|c|c|c|c|c|c|c|}
\hline \multirow{2}{*}{ Depth } & \multicolumn{2}{|c|}{$\mathrm{Mn}_{\mathrm{t}}$} & \multicolumn{2}{|c|}{$M n_{d}$} & \multicolumn{2}{|c|}{$M n_{o}$} & \multicolumn{2}{|c|}{$M n_{t}-M n_{d}$} & \multicolumn{2}{|c|}{$M n_{d}-M n_{o}$} & \multicolumn{2}{|c|}{$\mathrm{Mn}_{\mathrm{o}} / \mathrm{Mn}_{\mathrm{d}}$} & \multicolumn{2}{|c|}{$M n_{d} / M_{t}$} \\
\hline & Untr & $\operatorname{Tr}$ & Untr & $\mathrm{Tr}$ & Untr & $\operatorname{Tr}$ & Untr & $\operatorname{Tr}$ & Untr & $\operatorname{Tr}$ & Untr & $\mathrm{Tr}$ & Untr & $\operatorname{Tr}$ \\
\hline $\mathrm{cm}$ & & & & & & & $\mathrm{g} \mathrm{kg}^{-1}$ & & & & & & & \\
\hline $0-10$ & 4.7 at & $2.1 \mathrm{C}$ & $4.1 \mathrm{a}$ & $2.1 \mathrm{c}$ & $2.9 \mathrm{a}$ & $1.2 \mathrm{C}$ & 0.6 & 0.1 & 1.2 & 0.8 & 0.70 & 0.60 & 0.88 & 0.98 \\
\hline 10-20 & $5.0 \mathrm{a}$ & $2.4 \mathrm{C}$ & $4.4 \mathrm{a}$ & $2.2 \mathrm{c}$ & $3.5 \mathrm{a}$ & $1.3 \mathrm{C}$ & 0.6 & 0.2 & 0.9 & 0.9 & 0.80 & 0.60 & 0.89 & 0.92 \\
\hline 20-30 & $4.8 \mathrm{a}$ & $2.6 \mathrm{C}$ & $4.4 \mathrm{a}$ & $2.4 \mathrm{C}$ & $3.3 \mathrm{a}$ & $1.3 \mathrm{C}$ & 0.5 & 0.2 & 1.0 & 1.1 & 0.77 & 0.54 & 0.89 & 0.92 \\
\hline $30-50$ & $7.2 \mathrm{~b}$ & $2.9 \mathrm{C}$ & $5.8 \mathrm{~b}$ & $2.6 \mathrm{C}$ & $5.4 \mathrm{~b}$ & $1.8 \mathrm{C}$ & 1.4 & 0.3 & 0.5 & 7.0 & 0.92 & 0.71 & 0.81 & 0.90 \\
\hline 50-70 & $5.4 \mathrm{a}$ & $3.8 \mathrm{a}$ & $4.8 \mathrm{a}$ & $3.4 \mathrm{a}$ & $3.9 \mathrm{a}$ & $2.4 \mathrm{C}$ & 0.6 & 0.4 & 0.8 & 1.0 & 0.83 & 0.70 & 0.89 & 0.89 \\
\hline $70-100$ & $6.6 \mathrm{~b}$ & $4.0 \mathrm{a}$ & $5.8 \mathrm{~b}$ & $3.7 \mathrm{~b}$ & $4.4 \mathrm{ab}$ & $2.4 \mathrm{C}$ & 0.8 & 0.3 & 1.4 & 1.2 & 0.75 & 0.66 & 0.89 & 0.92 \\
\hline
\end{tabular}

+ Values followed by the same letter in the analyzed Mn oxides for untreated and treated soils are not significantly different $(P<0.05)$.

The $\mathrm{Fe}_{\mathrm{d} /} / \mathrm{Fe}_{\mathrm{t}}$ ratio was used to assess the extent of weathering of primary Fe-bearing minerals and it has also been used to estimate the relative soil age (Blume and Schwertmann, 1969; Arduino et al., 1986). The $\mathrm{Fe}_{\mathrm{d} /} \mathrm{Fe}_{\mathrm{t}}$ ratios ranged between 0.59 and 0.70 , indicating that significant amounts of Fe silicate were still present in the soil. The weatherability of the parent material and the soil age are the factors that influence this ratio the most.

The values of total $\mathrm{Mn}$ oxides, $\mathrm{Mn}_{\mathrm{o}}$, and $\mathrm{Mn}_{\mathrm{d}}$ are shown in Table 5. The mean values for total Mn contents increased with depth, with the highest value in the 30- to 50-cm depth, similar to Fe contents. These values were similar to $\mathrm{Mn}_{\mathrm{d}}$ (free $\mathrm{Mn}$ oxides), showing that practically all Mn present in the soils was extractable with DCB, that is to say, they were free Mn oxides. The effect of the amendment greatly decreased the values of total $\mathrm{Mn}$ and also the values of $\mathrm{Mn}_{\mathrm{d}}$ and $\mathrm{Mn}_{\mathrm{o}}$. This behavior can be due to the formation of soluble complexes of $\mathrm{Mn}$ with the organic compounds in the wastewater. The values of total Mn content after the organic amendment presented a notable increase with depth when compared with the untreated soil-almost double at the lowest depth compared with the upper horizons. It is known that microbial decomposition of organic matter leads to reducing conditions by utilizing free $\mathrm{O}_{2}$ in the soil atmosphere and free metal oxides (mostly Fe and Mn), which results in the production of $\mathrm{CO}_{2}$ and organic acids, under which Fe and $\mathrm{Mn}$ become free in the soil solution (Mandal and Mitra, 1982). In soils, microorganisms use $\mathrm{Fe}(\mathrm{III})$ and $\mathrm{Mn}$ (IV) as final electron acceptors (and organic matter as the electron donor) when $\mathrm{O}_{2}$ is depleted. The resulting reduced forms of these elements are much more soluble than their oxidized counterparts. Normally, Mn is reduced before Fe. The results seem to confirm this expectation.

The difference between the $\mathrm{Mn}_{\mathrm{d}}$ and $\mathrm{Mn}_{\mathrm{o}}$ contents was the crystalline Mn oxides. The wastewater addition did not significantly change the content of the crystalline Mn oxides in the topsoil.

The content of $\mathrm{Al}$ oxides $\left(210 \mathrm{~g} \mathrm{~kg}^{-1}\right)$ was greater than the usual amount in soils (median $134 \mathrm{~g} \mathrm{~kg}^{-1}$; Bowen, 1979), and this was associated with the presence of $\mathrm{Al}$-containing clay minerals in this soil (such as kaolinite and smectite), as confirmed with XRD. Kaolinite is the clay mineral containing the greatest amount of $\mathrm{Al}$ in its structure (about $400 \mathrm{~g} \mathrm{~kg}^{-1}$ ) and smectite also contains a relatively large proportion (about $210 \mathrm{~g} \mathrm{~kg}^{-1}$ ) of $\mathrm{Al}$ (Newman, 1987). Aluminum contents remained constant after $40 \mathrm{yr}$ of irrigation with the wastewater, probably attaining equilibrium.

\section{Influence on Iron and Manganese Oxides in the Clay Fraction}

Table 6 shows the Fe contents, expressed as an oxide, extracted from the clay fraction with the different extractants. The values of $\mathrm{Fe}_{\mathrm{d}}$ and $\mathrm{Fe}_{\mathrm{o}}$ were less for the clay fraction than for the whole soil, and this was more noticeable for the short-rangeordered metal oxides (amorphous oxides). The irrigation with the wastewater increased twofold the amounts of the amorphous oxide in the top layer. This increase was parallel to the decrease in the content of crystalline Fe oxides, possibly because of the amorphization of these oxides due to the $\mathrm{pH}$ of the wastewater. The crystallinity index was less for the clay fraction than the soil, and it increased in the topsoil after amendment.

The addition of organics caused a decrease in the Mn content of crystalline oxides in the soil (Table 7), even in the subsoil (70-100 $\mathrm{cm})$; however, the amorphous $\mathrm{Mn}$ oxide content $\left(\mathrm{Mn}_{\mathrm{o}}\right)$ increased in the topsoil of the treated soils. Similarly to the Fe oxides, for Mn the index $\mathrm{Mn}_{\mathrm{o}} / \mathrm{Mn}_{\mathrm{d}}$ was lower in the clay fraction than in the soil, indicating that the short-range-ordered oxides were less in the clay fraction than in the whole soil (Table 4).

\section{Influence on Metal Leaching}

Movement of metals in soils requires that they should be in the soluble phase or associated with mobile particulates. It has been shown that metals such as $\mathrm{Zn}$ and $\mathrm{Cu}$ are complexed strongly by humic acids at $\mathrm{pH}$ levels around 4.5 to 5.0 (Waller and Pickering, 1992). Movement is essentially related to speciation of the metals in soils because, depending on the species,

Table 6. Average of Fe oxides extractable by dithionite-citrate-bicarbonate ( $\mathrm{Fe}_{\mathrm{d}}$ ), Fe oxides extractable by oxalate-oxalic acid in the dark $\left(\mathrm{Fe}_{\mathrm{o}}\right)$, and indices in the clay fraction of the untreated (Untr) and treated (Tr) soils.

\begin{tabular}{|c|c|c|c|c|c|c|c|c|}
\hline \multirow{2}{*}{ Depth } & \multicolumn{2}{|c|}{$\mathrm{Fe}_{\mathrm{d}}$} & \multicolumn{2}{|c|}{$\mathrm{Fe}_{\mathrm{o}}$} & \multicolumn{2}{|c|}{$F e_{d}-F e_{o}$} & \multicolumn{2}{|c|}{$\mathrm{Fe}_{\mathrm{o}} / \mathrm{Fe}_{\mathrm{d}}$} \\
\hline & Untr & $\mathrm{Tr}$ & Untr & $\mathrm{Tr}$ & Untr & $\operatorname{Tr}$ & Untr & $\mathrm{Tr}$ \\
\hline $\mathrm{cm}$ & & & & $g$ & & & & \\
\hline $0-10$ & 55.1 at & $49.4 \mathrm{a}$ & $3.6 \mathrm{~b}$ & $7.1 \mathrm{a}^{8}$ & 51.5 & 42.3 & 0.07 & 0.14 \\
\hline $10-20$ & $50.8 \mathrm{a}$ & $50.0 \mathrm{a}$ & $3.6 \mathrm{~b}$ & $5.0 \mathrm{ab}$ & 47.2 & 45.0 & 0.07 & 0.10 \\
\hline $20-30$ & $48.0 \mathrm{ab}$ & $46.0 \mathrm{~b}$ & $4.4 \mathrm{ab}$ & $4.8 \mathrm{ab}$ & 43.6 & 41.2 & 0.09 & 0.10 \\
\hline $30-50$ & $45.1 \mathrm{~b}$ & $49.7 \mathrm{a}$ & $5.6 \mathrm{ab}$ & $5.5 \mathrm{ab}$ & 39.5 & 44.2 & 0.12 & 0.11 \\
\hline 50-70 & $45.0 \mathrm{~b}$ & $40.0 \mathrm{c}$ & $4.3 \mathrm{ab}$ & $3.8 \mathrm{~b}$ & 40.7 & 35.7 & 0.10 & 0.09 \\
\hline $70-100$ & $43.1 \mathrm{~b}$ & $34.6 \mathrm{c}$ & $3.6 \mathrm{~b}$ & $3.1 \mathrm{~b}$ & 39.5 & 31.4 & 0.08 & 0.09 \\
\hline
\end{tabular}

t Values followed by the same letter in the analyzed Fe oxides for untreated and treated soils are not significantly different $(P<0.05)$. 
Table 7. Average of $\mathrm{Mn}$ oxides extractable by dithionite-citrate-bicarbonate $\left(\mathrm{Mn}_{\mathrm{d}}\right), \mathrm{Mn}$ oxides extractable by oxalate-oxalic acid in the dark $\left(\mathrm{Mn}_{\mathbf{0}}\right)$, and indices in untreated (Untr) and treated (Tr) soils.

\begin{tabular}{|c|c|c|c|c|c|c|c|c|}
\hline \multirow{2}{*}{ Depth } & \multicolumn{2}{|c|}{$M n_{d}$} & \multicolumn{2}{|c|}{$\mathrm{Mn}_{\mathrm{o}}$} & \multicolumn{2}{|c|}{$M n_{d}-M n_{o}$} & \multicolumn{2}{|c|}{$M n_{o} / M_{d}$} \\
\hline & Untr & $\mathrm{Tr}$ & Untr & $\mathrm{Tr}$ & Untr & $\mathrm{Tr}$ & Untr & $\mathrm{Tr}$ \\
\hline $\mathrm{cm}$ & & & & & & & & \\
\hline $0-10$ & $1.9 \mathrm{a}+$ & $0.8 \mathrm{~b}$ & $0.1 \mathrm{~b}$ & $0.3 \mathrm{a}$ & 1.8 & 0.5 & 0.05 & 0.40 \\
\hline $10-20$ & $1.9 \mathrm{a}$ & $0.9 \mathrm{~b}$ & $0.1 \mathrm{~b}$ & $0.2 \mathrm{a}$ & 1.8 & 0.7 & 0.05 & 0.22 \\
\hline 20-30 & $1.9 \mathrm{a}$ & $1.0 \mathrm{~b}$ & $0.2 \mathrm{a}$ & $0.2 \mathrm{a}$ & 1.7 & 0.8 & 0.11 & 0.20 \\
\hline $30-50$ & $2.5 \mathrm{a}$ & $1.1 \mathrm{~b}$ & $0.3 a$ & $0.3 \mathrm{a}$ & 2.2 & 0.8 & 0.12 & 0.27 \\
\hline $50-70$ & $1.6 \mathrm{a}$ & $0.9 \mathrm{~b}$ & $0.3 a$ & $0.3 \mathrm{a}$ & 1.3 & 0.6 & 0.19 & 0.33 \\
\hline 70-100 & $1.8 \mathrm{a}$ & $1.1 \mathrm{~b}$ & $0.3 \mathrm{a}$ & $0.3 \mathrm{a}$ & 1.5 & 0.8 & 0.17 & 0.27 \\
\hline
\end{tabular}

+ Values followed by the same letter in the analyzed Mn oxides for untreated and treated soils are not significantly different $(P<0.05)$.

they may have different potential for undergoing mobilization by organic or inorganic ligands that are present in the soil solution (McBride, 1989; Li and Shuman 1997a).

The mean values of $\mathrm{Cu}$ in the upper horizons were larger in the treated soils than the untreated soils, and similar for the other depths (Fig. 2). This behavior could be due to the interaction of this element with the soil OM, whose content is the highest in the upper horizon. Temminghoff et al. (1997) reported that dissolved $\mathrm{OM}$ enhanced the mobility of $\mathrm{Cu}$; however, Han and Thompson (2003) indicated that dissolved OM over the long term inhibited $\mathrm{Cu}$ mobility. The low mobility of some metals can be related to the retention of these elements in the upper layer by OM (Giusquiani et al., 1992), as observed in our experiments.

The mean values of $\mathrm{Zn}$ from untreated and treated soils (Fig. 2) indicated that irrigation with the wastewater mobilized this metal from the surface to subsurface horizons. Decreasing $\mathrm{pH}$ mobilizes most metals, and low $\mathrm{pH}$ favors more solubilization and hence mobility, but the decrease in treated soils was only 0.5 units. Therefore an enhanced transport of this metal by dissolved OM should be considered because of the increase in $\mathrm{Zn}$ concentration with depth. The low-molecularweights hydrophilic dissolved OM components are highly mobile and could influence metal transport in the soil system. Giusquiani et al. (1992) reported an increased mobility for heavy metals added to the soil by urban waste compost. Organic molecules with the capability to complex metals can potentially increase concentrations of these metals in soil solution by dissolution reactions at mineral surfaces (Ashworth and Alloway, 2004). The application of vinasse may increase some metal's mobility, because soluble organic ligands can form water-soluble complexes with metals ( $\mathrm{Li}$ and Shuman, 1997b). A process that affects heavy metal solubility may also influence heavy metal leaching in soils, explaining why the content of $\mathrm{Zn}$ was higher in the subsoil of the treated soils (Fig. 2).

The mean concentrations of Co for treated and untreated soils are also shown in Fig. 2. The complexes of the metal with the dissolved OM may contribute to the release of metals so that the values in the treated soils were less than those in the untreated profiles. Cobalt is one the divalent cations that is strongly complexed with OM according to the sequence $\mathrm{Cu}^{2+}>\mathrm{Co}^{2+}>\mathrm{Zn}^{2+}>$ $\mathrm{Fe}^{2+}>\mathrm{Mn}^{2+}$ (Stevenson, 1994). Moreover, part of the metal released is dissolved by other factors, probably by the slightly acidic nature of the supplied OM. In addition, Co is correlated with $\mathrm{Fe}$ and $\mathrm{Mn}$ oxides of soil because soil microorganisms use organic matter as an electron donor for reducing $\mathrm{Fe}(\mathrm{III})$ and $\mathrm{Mn}(\mathrm{IV})$. The resulting reduced forms of these elements are much more soluble than their oxidized counterparts and therefore they would leach through the soil profiles.

\section{Crop Yield}

In the treated soils there was a noteworthy increase in sugarcane production. The cultivar Cuba-8751 yielded mean values
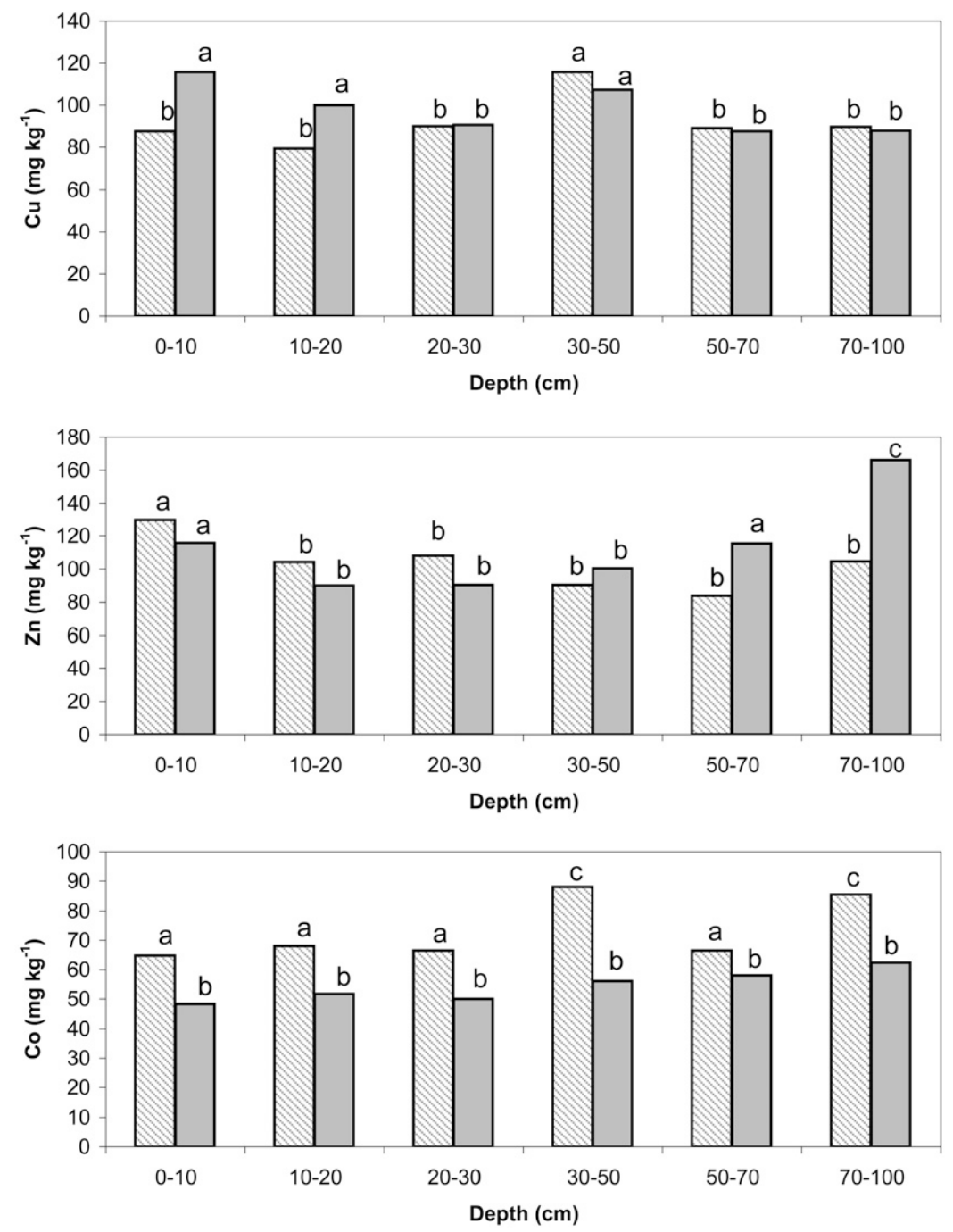

Fig. 2. Mean values of total $\mathrm{Cu}, \mathrm{Zn}$, and $\mathrm{Co}$ for untreated (patterned bars) and treated (shadowed bars) soils from 0 - to $100-\mathrm{cm}$ depth. Values followed by the same letter for untreated and treated soil do not differ significantly $(P<0.05)$. 
from the last $5 \mathrm{yr}$ of 24.88 and $76 \mathrm{Mg} \mathrm{ha}^{-1}$ for the untreated and treated soils, respectively.

\section{CONCLUSIONS}

The results presented here show that irrigation with wastewater from the sugarcane industry may be used successfully in agriculture. It increased crop yield and the organic matter content in the lower part of the soil profile. The large concentration of $\mathrm{K}$ in the wastewater increased $\mathrm{EC}$, but the $\mathrm{EC}$ values were less than the limiting values for salt tolerance of crops. Vinasse application yielded the intercalation of organic compounds in the clay mineral smectite. The formation of organo-mineral complexes and particle coating with Fe oxides produced little change in the particle-size distribution, but the increase in the poorly crystalline $\mathrm{Fe}$ oxyhydroxides in the upper horizon was very significant. The crystallinity of $\mathrm{Fe}$ oxyhydroxide in the soil decreased substantially because of dissolution and reprecipitation of these oxides by the acidic $\mathrm{pH}$ of the wastewater. Total and poorly crystalline Mn contents were also decreased. The applied wastewater contained soluble organic matter that complexed metals, favoring their leaching throughout the soil profile, which may eventually lead to deterioration of groundwater quality and a decrease in some micronutrient contents in the soils.

\section{ACKNOWLEDGMENTS}

The financial support of the Junta de Andalucía through the projects PAI RMN 166 and Exp. 92162/1 is greatly acknowledged.

\section{REFERENCES}

Arduino, E., E. Barberis, F. Ajmone-Marsan, E. Zanini, and M. Franchini. 1986. Iron oxides and clay minerals within profiles as indicators of soil age in northern Italy. Geoderma 37:45-55.

Ashworth, D.J., and B.J. Alloway. 2004. Soil mobility of sewage sludgederived dissolved organic matter, copper, nickel and zinc. Environ. Pollut. 127:137-144.

Benke, M.B., A.R. Mermut, and B. Chatson. 1998. Carbon-13 CP/MAS NMR and DR-FTIR spectroscopic studies of sugarcane distillery waste. Can. J. Soil Sci. 78:227-236.

Benke, M.B., A.R. Mermut, and H. Shariatmadari. 1999. Retention of dissolved organic carbon from vinasse by a tropical soil, kaolinite, and $\mathrm{Fe}$ oxides. Geoderma 91:47-63.

Blume, H.P., and U. Schwertmann. 1969. Genetic evaluation of profile distribution of aluminum, iron and manganese oxides. Soil Sci. Soc. Am. Proc. 33:438-444.

Bowen, H.J.M. 1979. Environmental chemistry of the elements. Academic Press, New York.

Bresler, E., B.L. McNeal, and D.L. Carter. 1982. Saline and sodic soils. PrinciplesDynamics_-Modeling. Adv. Ser. Agric. Sci. 10. Springer-Verlag, Berlin.

Casarini, D.C.P., R.C.D. Cunha, and B. Masei Filho. 1987. Effect of irrigation with vinasse and the dynamics of its constituents in the soil. 2 . Microbiological aspects. Water Sci. Technol. 19:167-176.

Cruz, R.L., A.M. Righetto, and M.A. Nogueira. 1991. Experimental investigation of soil and groundwater impacts caused by vinasse disposal. Water Sci. Technol. 24:77-85.

Del Castilho, P., W.J. Chardon, and W. Salomon. 1993. Influence of cattle manure slurry application on the solubility of cadmium, copper, and zinc in a manured acidic, loamy-sand soil. J. Environ. Qual. 22:689-697.

Diaz-Barrientos, E., L. Madrid, C. Maqueda, E. Morillo, E. Ruiz-Cortes, E. Basallote, and M. Carrillo. 2003. Copper and zinc retention by an organically amended soil. Chemosphere 50:911-917.

Fitzpatrick, R.W., and U. Schwertmann. 1982. Al-substituted goethite: An indicator of pedogenetic and other weathering environments in South Africa. Geoderma 27:335-347.

Gee, G.W., and J.W. Bauder. 1979. Particle-size analysis by hydrometer: A simplified method for routine textural analysis and a sensitivity test of measurement parameters. Soil Sci. Soc. Am. J. 43:1004-1007.

Gloeden, E., R.C.A. Cunha, M.J.B. Fraccoroli, and R.W. Cleary. 1991. The behaviour of vinasse constituents in the unsaturated and saturated zones in the Botucatu Aquifer recharge area. Water Sci. Technol. 24:147-157.

Giusquiani, P.L., G. Gigliotti, and D. Businelli. 1992. Heavy metals in the environment: Mobility of heavy metals in urban waste-amended soils. J. Environ. Qual. 21:330-335.

Han, N., and M.L. Thompson. 2003. Impact of dissolved organic matter on copper mobility in aquifer material. J. Environ. Qual. 32:1829-1836.

Li, Z.B., and L.M. Shuman. 1997a. Mobility of $\mathrm{Zn}, \mathrm{Cd}$ and $\mathrm{Pb}$ in soils as affected by poultry litter extract: II. Redistribution among soil fractions. Environ. Pollut. 95:227-234.

Li, Z.B., and L.M. Shuman. 1997b. Mobility of Zn, Cd and Pb in soils as affected by poultry litter extract: I. Leaching in soil columns. Environ. Pollut. 95:219-226.

Madejon, E., R. Lopez, J.M. Murillo, and F. Cabrera. 2001. Agricultural use of three (sugar-beet) vinasse composts: Effect on crops and chemical properties of a Cambisol soil in the Guadalquivir river valley (SW Spain). Agric. Ecosyst. Environ. 84:55-65.

Madrid, L., and E. Diaz-Barrientos. 1998. Release of metals from homogeneous soil columns by wastewater from an agricultural industry. Environ. Pollut. 101:43-48.

Mandal, L.N., and R.R. Mitra. 1982. Transformation of iron and manganese in rice soils under different moisture regimes and organic matter application. Plant Soil 69:45-56.

Mattiazzo, M.E., and N.A. Dagloria. 1987. Effect of vinasse on soil acidity. Water Sci. Technol. 19:1293-1296.

McBride, M.B. 1989. Reaction controlling heavy metal solubility in soils. Adv. Soil Sci. 10:1-57.

McKeague, J.A., J.E. Brydon, and N.M. Miles. 1971. Differentiation of forms of extractable iron and aluminum in soils. Soil Sci. Soc. Am. Proc. 35:33-38.

Mehra, O.P., and M.L. Jackson. 1960. Iron oxide removal from soils and clays by a dithionite-citrate system buffered with sodium bicarbonate. Clays Clay Miner. 7:317-327.

Ministerio de Agricultura de Cuba. 1985. Suelos de la provincia de La Habana, Cuba.

Newman, A.C.D. 1987. Chemistry of clays and clay minerals. Mineral. Soc. Monogr. 6. Longman Scientific and Technical, London.

Perez-Rodríguez, J.L., C. Maqueda, and A. Justo. 1990. Mineralogy of soils containing phyrophyllite from southwest Spain: Isolation and identification of the mineral. Soil Sci. 150:671-679.

Qualls, R.G., and B.L. Haines. 1991. Geochemistry of dissolved organic nutrients in water percolating through a forest ecosystem. Soil Sci. Soc. Am. J. 55:1112-1123.

Raulund-Rasmussen, K., O.K. Boorgard, H.C.B. Hansen, and M. Olsson. 1998. Effect of natural organic soil solutes on weathering rates of soil minerals. Eur. J. Soil Sci. 49:397-406.

Rodriguez-Rubio, P., E. Morillo, L. Madrid, and C. Maqueda. 2003. Retention of copper by a calcareous soil and its textural fractions: Influence of amendment with two agroindustrial residues. J. Soil Sci. 54:401-409.

Schultz, L.G. 1964. Quantitative interpretation of mineralogical composition from xray and chemical data for the Pierre Shale. U.S. Geol. Surv. Prof. Pap. 391-C.

Schwertmann, U. 1966. Inhibitory effect of soil organic matter on crystallization of amorphous ferric hydroxide. Nature 212:645-646.

Soil Survey Staff. 1999. Soil Taxonomy: A basic system of soil classification for making and interpreting soil surveys. USDA Agric. Handbk. 436. U.S. Gov. Print. Office, Washington, DC.

Stepkowska, E., C. Maqueda, E. Morillo, R. Lopez, and J.L. Perez-Rodríguez. 2001. Changes in physico-chemical properties of soils fertilized by agroindustrial residues. Fresenius Environ. Bull. 3:300-304.

Stevenson, F.J. 1994. Humus chemistry-Genesis, compositions, reactions. John Wiley \& Sons, New York.

Strobel, B.W., O.K. Borggard, H.C.B. Hansen, M.K. Andersen, and K. Raulund-Rasmussen. 2005. Dissolved organic carbon and decreasing pH mobilize cadmium and copper in soil. Eur. J. Soil Sci. 56:189-196.

Temminghoff, E.J.M., S.E.A.T.M. Van der Zee, and F.A.M. de Haan. 1997. Copper mobility in a copper-contaminated sandy soil as affected by $\mathrm{pH}$ and solid and dissolved organic matter. Environ. Sci. Technol. 31:1109-1115.

Tisdale, S.L., W.L. Nelson, J.D. Beaton, and J.L. Havlin. 1993. Soil fertility and fertilizer. 5th ed. Macmillan Publ. Co., New York.

Waller, P.A., and W.F. Pickering. 1992. Effect of time and $\mathrm{pH}$ on the lability of copper and zinc sorbed on humic-acid particles. Chem. Speciation Bioavailability 4:29-41. 